\title{
Cola species of the limestone forests of Africa, with a new, endangered species, Cola cheringoma (Sterculiaceae), from Cheringoma, Mozambique
}

\author{
Martin Cheek $^{1}$ (D), Quentin Luke ${ }^{2}$, Hermenegildo Matimele ${ }^{1,3}$, Aurélio Banze $^{3}$ \& Poppy Lawrence ${ }^{4}$
}

Summary. Cola cheringoma is described from the limestone gorge forest of the Cheringoma Plateau in Sofala Province of Central Mozambique. Tentatively treated previously as C. clavata Mast., it differs in being restricted to limestone substrate, the leaves drying white-green below (not on sandy soils, drying dark greybrown). The tepal number of female flowers is 5 (not $(5-) 6$ ), staminode number 5 (not 8), and the indumentum of the outer perianth covers only $50-60 \%$ of the surface with two distinct hair classes (not $100 \%$ coverage with a single hair type). The species is assessed as EN B2ab(iii) using the IUCN 2012 standard due to threats from the low number of locations, quarrying, and habitat modification. The Cola species growing in forest on limestone in tropical Africa are mapped and reviewed with respect to their status as obligate or facultative calcicoles, and with respect to their probable evolutionary origin. Based on morphological characters, adaptation to limestone habitats has probably occurred at least four times in the genus. Forests on limestone are rare and threatened in tropical Africa: only thirteen locations are known with certainty: these occur in Kenya (10 locations), Tanzania (2 locations) and Mozambique (1 location).

Key Words. Calicole, conservation, mining, monograph, quarrying, taxonomy, threatened.

\section{Introduction}

For most of the twentieth century Cola Schott. \& Endl. was included in tribe Sterculieae of Sterculiaceae sensu lato of the core Malvales. Phylogenetic investigation of Malvales showed that in place of the traditional four families recognised (Malvaceae, Bombacaceae, Sterculiaceae, Tiliaceae) there is a choice of either recognising nine subfamilies in a super-Malvaceae (Bayer et al. 1999; Bayer \& Kubitzki 2003) or recognising the same units as the families, Bombacaceae, Brownlowiaceae, Byttneriaceae, Dombeyaceae, Durionaceae, Helicteraceae, Malvaceae sensu stricto, Sparrmanniaceae, Sterculiaceae and Tiliaceae (Baum et al. 1998; Cheek \& Dorr 2007; Cheek in Heywood et al. 2007; Skema 2012; Wilkins \& Whitlock 2012). Cola can therefore now be placed either in Malvaceae-Sterculioideae or Sterculiaceae s.s. The second approach is preferred since it is less cumbersome and creates less taxonomic instability (Cheek \& Dorr 2007).

The Sterculiaceae sensu stricto are characterised within Malvales by unisexual flowers with a single perianth whorl that lack an epicalyx. The male flowers have an androgynophore bearing the anthers in a terminal capitulum or ring, the gynoecium vestigial and inconspicuous. Female flowers usually have a sessile or subsessile gynoecium developing into an apocarpous fruit of $(1-) 4-5(-15)$ fruitlets or mericarps, the base surrounded by indehiscent anthers. The family is pantropical, with c. 415 species arranged in 13 genera (Cheek in Heywood et al. 2007).

Pterygota Schott \& Endl., pantropical, with dehiscent, woody mericarps containing dry, winged seeds, is in a sister relationship with Cola, while Octolobus Welw., confined to tropical Africa, with numerous spirally inserted indehiscent mericarps, is sister to Pterygota-Cola combined (Wilkie et al. 2006). The remaining genera of the Cola clade, Hildegardia Schott \& Endl., Firmiana Marsili, Pterocymbium R.Br., and Scaphium Schott \& Endl. all have winged fruitlets and are wind-dispersed, and all but the first are confined to SE Asia and adjoining areas. In comparison, the pantropical genus Sterculia L., sometimes confused with Cola, is in an entirely different subclade, and always has dehiscent fruit with the seeds with radicle directed away from the

\footnotetext{
Accepted for publication 8 August 2019. Published online 24 September 2019

1 Science, Herbarium, Royal Botanic Gardens, Kew, Richmond, Surrey, TW9 3AE, U.K. e-mail: m.cheek@kew.org

2 East African Herbarium, National Museums of Kenya, Museum Hill Road, P.O. Box 45166, Nairobi 00100, Kenya.

3 National Herbarium of Mozambique, Institute for Agricultural Research of Mozambique, P.O. Box 3658, Mavalane, Maputo 8, Mozambique.

${ }^{4}$ College of Life and Environmental Sciences, University of Exeter, Exeter EX4 4QD, U.K.
} 
hilum and hard-coated, borne on a placenta with irritant hairs.

The genus Cola is mostly confined to evergreen lowland and submontane forest in continental subsaharan Africa with only two species, C. cordifolia (Cav.) R.Br. and C. gigantea A.Chev., in deciduous forest or woodland. With $100-125$ species of trees and shrubs, Cola is the most species-diverse genus in the Sterculiaceae. The genus is characterised by indehiscent (rarely at length dehiscent) fleshy orange or red mericarps containing seeds with a soft, fleshy, edible seedcoat, the radicle directed towards the hilum. The endocarp is glabrous. Seed is thought to be dispersed mainly by monkeys and apes, which may explain the absence of Cola from oceanic islands near Africa such as Madagascar. While some Cola species are widespread, many are extremely local, and some are known from few or single forest patches and so are vulnerable to extinction. Eight species of Cola in Cameroon, the most species diverse country for the genus, have been assessed as threatened (Onana \& Cheek 2011). Cola nitida (Vent.) Schott. \& Endl. and C. acuminata (P.Beauv.) Schott. \& Endl. are planted throughout the tropics for their seeds, which act as stimulants when chewed and are an ingredient of the eponymous and ubiquitous 'Cola' soft drinks. Two other species also have stimulant seeds, but are only locally cultivated (Cheek 2002a; Cheek \& Dorr 2007).

Most species of Cola occur in Tropical Africa, with only three species, C. natalensis Oliv., C. dorrii Cheek and C. greenwayi Brenan in South Africa (Cheek et al. 2018a). In East Africa (Uganda, Kenya and Tanzania), 21 species are native (Cheek \& Dorr 2007). However, West and Central Africa are the heartland of Cola. The largest number of species for any flora region is that in the Flora of West Tropical Africa (FWTA), with 42 species, and with an additional nine imperfectlyknown species (Keay \& Brenan 1958). Thirty-three species are recorded from Gabon (Hallé 1961) and 32 from Congo-Kinshasa (Germain 1963). The Flore du Cameroun account awaits completion. However, Kenfack et al. (2018) report 43 species from Cameroon, most of which are confined to the Cross-Sanaga interval (Cheek et al. 2001). The genus was last monographed by Schumann (1900) when 33 species were recognised. Although Brenan did much research on the genus throughout its range, he confined himself, largely, to publishing accounts of new species (e.g. Brenan \& Keay 1955).

During preparation for a monograph (Cheek 2002a, b; Cheek \& Dorr 2007; Cheek et al. 2018a) and for conservation assessments of all known species of Cola, 10 specimens from the limestone area of Cheringoma, Mozambique were observed. These had been collected in a series of five visits from Nov. 1957 - Oct 1962 by António de
Figueiredo Gomes e Souza (1896 - 1973) of the Mozambique Agricultural Service who produced the Dendrologia de Moçambique (Gomes e Sousa 1967; Burrows et al. 2018). This intensive targetting of the Cheringoma limestone Cola by Gomes e Sousa, which extended over several years, suggests that he had identified that it was an interesting taxon, and that he repeatedly but unsuccessfully sought material of stages additional to the male flowering collection he had made at his first gathering. Finally, he identified his specimens as "Cola ?clavata" indicating that he considered that they might represent a different species. The LMA duplicate shows that the material puzzled other botanists. It is annotated "Cola clavata Mast.?, Kew", but also "Cola of natalensis Oliv. Pretoria", and finally it was identified as C. greenwayi in 1971, by Graca Silva at LMA where it was filed as such (C. Langa pers. comm. 2018). In the last ten years there have been two botanical surveys to the Cheringoma limestone gorges (Wursten 2014). In one of these, gathering material for the excellent "Trees \& Shrubs Mozambique" (Burrows et al. 2018), sight records were made in three different gorges of a Cola ascribed to C. mossambicensis Wild (Burrows et al. 2012). It is most likely that this was also misidentification for the species described here as new to science.

Limestone substrates around the world are renowned for harbouring narrowly endemic species, and new species narrowly endemic to limestone are still being discovered frequently, such as species of Polyalthia Blume (Annonaceae) in Peninsular Malaysia (Turner et al. 2018), Pilea (Urticaceae) from China (Monro et al. 2012), Begonia (Begoniaceae) from karst at the Sino-vietnamese border (Chung et al. 2014) or in Borneo (Sang et al. 2013, describing 13 new species from Sarawak), Nepenthes (Nepenthaceae) in Indonesian New Guinea (Cheek et al. 2018b) and sometimes even genera, e.g. Khaosokia caricoides D.A.Simpson, Chayam \& J.Parn., a monotypic genus of the Cyperaceae in Thailand (Simpson et al. 2005). In the Americas, Ficus bonijesulapensis R.M.Castro in Moraceae (Castro \& Rapini 2006), Ceiba rubriflora Carv.-Sobr. \& L.P.Queiroz in Bombacaceae (Carvalho-Sobrinho \& Queiroz 2008), Oxalis calcicola Fiaschi in Oxalidaceae (Fiaschi 2014) and the new Gesneriaceae genus Chautemsia calcicola A.O.Araujo \& V.C.Souza (Araújo et al. 2010) are all examples from Brazil. However far fewer botanical studies have focussed on species of limestone habitats in tropical Africa.

\section{Materials and Methods}

Names of species and authors follow IPNI (continuously updated). Nomenclatural practice fol- 
lows Turland et al. (2018). Herbarium material was examined with a Leica Wild M8 dissecting binocular microscope fitted with an eyepiece graticule measuring in units of $0.025 \mathrm{~mm}$ at maximum magnification. The drawing was made with the same equipment with a Leica 308700 camera lucida attachment. Specimens were inspected from the following herbaria: BM, BNRH, EA, FHO, K, LMA, PRE. The format of the description follows those in other papers describing new species in Cola, e.g. Cheek (2002a, b). All specimens indicated "!" have been seen by the first author. Points were georeferenced using locality information from herbarium specimens. The map was made using ArcMap version 10.5, with additional layers showing protected areas (UNEP-WCMC 2017) and lakes (ESRI 1992).
The conservation assessment follows the IUCN (2012) standard. Herbarium codes follow Index Herbariorum (Thiers, continuously updated).

\section{Results}

The Gomes e Sousa specimens collected at Cheringoma resemble those of Cola clavata but can be separated by the characters shown in Table 1. Even in the vegetative state, the two species can be distinguished by the differences in colour of the dried leaf-blades, and of the differences in the bud-scales and stem indumentum. No other Cola species have been recorded from limestone in Mozambique, nor in fact for the entire Flora Zambesiaca area (Wild 1961), although many species of Cola do occur on limestone in Tanzania \& Kenya (see discussion below). A key to the species of Cola in Mozambique is provided below.

Key to the species of Cola in the Flora Zambesiaca area (Mozambique, Zimbabwe, Zambia, Malawi \& Botswana)

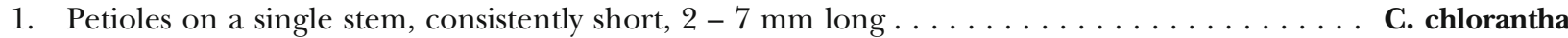
Petioles on a single stem varying from $4-5 \mathrm{~mm}$ to at least $30 \mathrm{~mm}$ long, in most species to $60-100(-270) \mathrm{mm}$

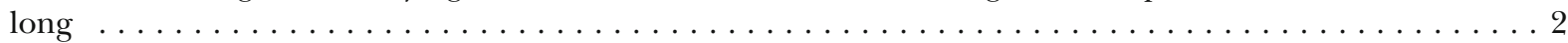

2. Young stems densely covered in orange or reddish-brown indumentum $\ldots \ldots \ldots \ldots \ldots \ldots \ldots \ldots$ Young stems glabrous to very sparsely and inconspicuously hairy $\ldots \ldots \ldots \ldots \ldots \ldots \ldots \ldots$

3. Occurring in forest $<900 \mathrm{~m}$ altitude; longest petiole to $10 \mathrm{~cm}$ long; leaf-blade $14-21 \times 7-11 \mathrm{~cm}$; young stems and petioles with a thick scurfy felt-like layer of red-brown hairs that is shed to reveal white

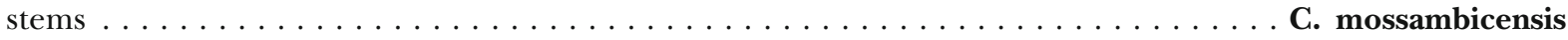
Occurring at $>1100 \mathrm{~m}$ altitude; petioles $0.3-4(-5.6) \mathrm{cm}$ long; leaf-blade $3-16 \times 1-6 \mathrm{~cm}$; stems with subscabrid, persistent, red or black indumentum, stems greyish-brown $\ldots \ldots \ldots \ldots \ldots$ C. greenwayi

4. Inflorescences multiple-flowered; pedicels $4-6 \mathrm{~mm}$ long; perianth lobes (3-) $3.5-4.5 \times 1.5-2(-2.5) \mathrm{mm}$; stipules $3 \mathrm{~mm}$ long $\ldots \ldots \ldots \ldots \ldots \ldots \ldots \ldots \ldots \ldots \ldots \ldots \ldots \ldots \ldots \ldots \ldots \ldots \ldots$ discoglypremnophylla Inflorescences single-flowered; pedicels $7-10 \mathrm{~mm}$ long; perianth lobes $4-5.5 \times 2-3.1 \mathrm{~mm}$; stipules $>8.5 \mathrm{~mm}$

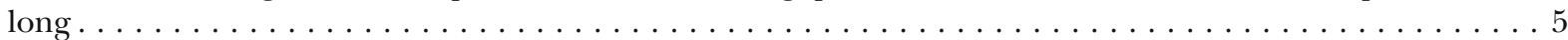

5. Leaf-blades discolorous, light green above, white-green below; indumentum of young stems sparsely white peltate-stellate hairy, hairs persistent for a season; abaxial surface of tepals with $50-60 \%$ indumentum

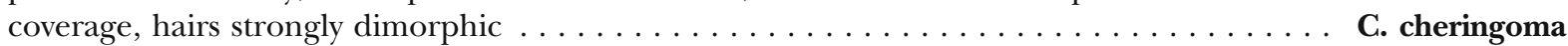
Leaf-blades concolorous, dark grey-brown on both surfaces; indumentum of young stems moderately densely red stellate hairy, hairs early caducous; abaxial surface of tepals with $100 \%$ indumentum coverage, hairs

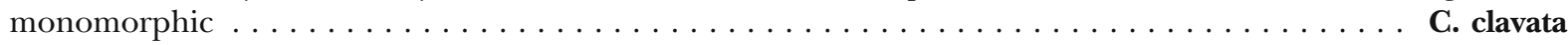

Cola cheringoma Cheek sp. nov. Type: Mozambique, Sofala Province, Cheringoma Distr., Condué R., calcareous soils, fl. 6 Nov. 1957, Gomes e Sousa 4441 (holotype K!; isotypes K!; LMA!).

http://www.ipni.org/urn:lsid:ipni.org:names:60479325-2

Dioecious (probably), evergreen, small tree (3-) $4-7 \mathrm{~m}$ tall; trunk characters not reported. Leafy stems terete, c. $3 \mathrm{~mm}$ diam., main shoots c. $12 \mathrm{~cm}$ long each season, spur-shoots c. $2 \mathrm{~cm}$ long, epidermis white, smooth, lenticels not conspicuous, current season's growth sparsely covered with white, appressed peltate-stellate 7 - 10-armed hairs $0.2-0.25 \mathrm{~mm}$ diam., the arms tapering to a point from the peltate base; previous season's stems longitudinally ridged, discoloured by black epiphytic patches, cicatrices raised, glabrescent. Bud scales c. 5 , ovate, $2.25 \times 1.5 \mathrm{~mm}$, slightly concave, apiculate, midrib raised on outer surface; indumentum white, stellate, 8 - 9-armed, 0.3 $0.4 \mathrm{~mm}$ diam., dense. Leaves 3 - 14 over the length of a season's growth, alternate, spirally arranged leaves; at anthesis the distalmost leaves subsessile, with the smallest blades, the leaves produced at the beginning of the season with the longest blades and longest petioles. Leaf blades discolorous, green to yellowish-green on upper surface, lower surface white-green, largest leaves (produced at beginning of 
Table 1. Characters distinguishing Cola cheringoma from Cola clavata (data for C. clavata from Simão 1202 (K, LMA) and Kirk 235 (holotype K).

\begin{tabular}{|c|c|c|}
\hline Character & Cola cheringoma & Cola clavata \\
\hline Substrate & calcareous-clay & sandy soils \\
\hline Leaf blade colour on drying & $\begin{array}{l}\text { discolorous light green above; } \\
\text { white-green below }\end{array}$ & $\begin{array}{l}\text { concolorous, dark grey-brown on both } \\
\text { surfaces }\end{array}$ \\
\hline Bud-scales & $\begin{array}{l}\text { ovate with raised midrib, apex } \\
\text { rounded but with short apiculus }\end{array}$ & subulate, apex narrowly acute \\
\hline $\begin{array}{l}\text { Innermost bracts (shape, texture } \\
\text { and length: breadth ratio) }\end{array}$ & $\begin{array}{l}\text { orbicular, concave, coriaceous; } \\
\text { length:breadth ratio } 1: 1\end{array}$ & $\begin{array}{l}\text { narrowly rhombic-rectangular, } \\
\text { membranous; length:breadth ratio10:1 }\end{array}$ \\
\hline Indumentum of young stems & $\begin{array}{l}\text { sparsely white peltate-stellate hairy, } \\
\text { hairs persistent for a season }\end{array}$ & $\begin{array}{l}\text { moderately densely red stellate hairy, hairs } \\
\text { early caducous }\end{array}$ \\
\hline $\begin{array}{l}\text { Predominant colour on drying of } \\
\text { inner/outer surface of tepals }\end{array}$ & black/black & red-brown/golden-brown \\
\hline Indumentum coverage & $50-60 \%$ & $100 \%$ \\
\hline \multicolumn{3}{|c|}{ Indumentum of outer surface of tepal lobes } \\
\hline Number of hair types & 2 distinct hair types & one hair type \\
\hline Orientation of hair arms & along long axis of tepal lobe & radial \\
\hline Tepal number (female flowers) & 5 & $(5-) 6$ \\
\hline $\begin{array}{l}\text { Staminode number (female } \\
\text { flowers) }\end{array}$ & 5 & 8 \\
\hline
\end{tabular}

season), oblanceolate or elliptic $(8.7-) 11.7-17.4(-$ $20.3) \times(3.9-) 4.8-7.8(-9.7) \mathrm{cm}$, apex shortly acuminate, acumen $0.5-0.8 \mathrm{~mm}$ long, base acute, obtuse or rounded; smallest leaves (produced at end of season) ovate, $(0.7-) 1-2.5(-4.7) \times(0.3-) 0.4-$ $1.1(-1.5) \mathrm{cm}$, apex acuminate, base cordate. Secondary nerves $4-6(-7)$ on each side of the midrib, arising at c. $45^{\circ}$ from the midrib, arching very gradually towards the margin, in the distal half of the blade the nerves often connecting with the secondary nerve above, forming an incomplete looping marginal nerve $2 \mathrm{~mm}$ from the margin, domatia absent; tertiary and quaternary nerves forming a prominent reticulum, glabrous. Petioles terete, $(2.3-) 3-8.4 \mathrm{~cm}$ long (longest leaves) and $0.1-0.4 \mathrm{~cm}$ long (shortest leaves), c. $1 \mathrm{~mm}$ wide, pulvini $2.5-3 \mathrm{~mm}$ long at apex and base of petiole of the longer leaves, indumentum of sparse simple, white ascending hairs $0.1 \mathrm{~mm}$ long, c. $5 \%$ cover, at length glabrescent; pulvini densely covered in 8 - 9-armed translucent stellate hairs $0.075-0.1 \mathrm{~mm}$ diam., $90-100 \%$ cover. Stipules caducous, lanceolate, $8.75 \times 2 \mathrm{~mm}$, proximal third widest, concave, distal part linear. Inflorescences 1flowered, flower buds developing in dormant season on previous (mainly) and current season's growth, 1 4 per leaf axil, from several nodes in succession; buds globose, c. $4 \mathrm{~mm}$ diam. pre-anthesis, protected by $6-8$ concave, suborbicular bracts (Fig. 1N). Bracts slightly broader than long, suborbicular $2 \mathrm{~mm}$ long, $2.3 \mathrm{~mm}$ wide, apex rounded with margin slightly hooded, margin densely hairy, inner surface with 10 - 12 equal, parallel, equally-spread nerves; outer surface densely appressed hairy, hairs simple $0.2-0.6 \mathrm{~mm}$ long, intermixed with inconspicuous sparse 4 - 8-armed stellate hairs $0.5-0.75 \mathrm{~mm}$ long, the arms directed to either base or apex of the bract. Flowers opening while stem apex is dormant, from stems of current and previous season's growth; flower buds 1-flowered, 1 several per axil, opening synchronously. Pedicels 7 $7.5 \mathrm{~mm}$ long (male flowers), $0.5-0.6 \mathrm{~mm}$ diam., not articulated, proximal $1.5 \mathrm{~mm}$ swollen, $1 \mathrm{~mm}$ diam., bearing the scars of four bracts, indumentum of sparse stellate hairs, 3 - 6-armed, $0.2-0.3 \mathrm{~mm}$ diam., arms mainly directed towards base or apex of pedicel (Fig. 1M). Female pedicels (Fig. 1L) with hairs denser, larger, 0.3 - $0.5 \mathrm{~mm}$ diam., 5 - 7-armed. Perianth divided by $4 / 5$ into $5 \pm$ patent lobes, each $4.5-5 \mathrm{~mm}$ long, 2.5 - $3.5 \mathrm{~mm}$ wide, the slender margins inflexed, forming a raised rim c. $0.2 \mathrm{~mm}$ high, outer surface 50 - $60 \%$ covered in dimorphic stellate hairs (Fig. 1K): type 1 hairs cover $40-50 \%$ of the surface, so that the hairs nearly touch each other, $0.1-0.13 \mathrm{~mm}$ diam., 3 - 6-armed, white, type 2 hairs sparse, larger, 0.25 $0.5 \mathrm{~mm}$ diam., 7 - 10-armed, the arms directed along axis of lobe golden-brown. Inner surface with minute translucent vesicles densely covering the surface of the lobes, the inner, unlobed part of the perianth slightly domed, glabrous, stellate hairs absent from inner surface apart from a few white filiform stellate hairs towards the tips of the lobes. Male flowers $16-21 \mathrm{~mm}$ wide, with an androphore $3-3.3 \mathrm{~mm}$ long, cylindrical, $0.2 \mathrm{~mm}$ diam. at base, $0.15 \mathrm{~mm}$ wide near apex, glabrous, apart from densely pubescent ring at the junction with the perianth, the hairs yellow, erect, simple $0.05 \mathrm{~mm}$ long; anthers uniseriate, 10, glabrous, in a disc $1-1.3 \mathrm{~mm}$ long, $2.5-2.7 \mathrm{~mm}$ diam.; ovary vestigial, concealed within anther head (Fig. 1G \& H). Female flowers $14 \mathrm{~mm}$ wide, with androphore absent; anthers at base of ovary, not reduced in size; ovary depressed globose, $1.8 \mathrm{~mm}$ long, $2.2 \mathrm{~mm}$ diam., inconspicuously 5-lobed, densely stellate hairy, hairs 8 - 10-armed, $0.4-0.5 \mathrm{~mm}$ diam., arms stiff, ascending. 
Style $1.4 \mathrm{~mm}$ long, $0.9 \mathrm{~mm}$ diam., indumentum as ovary; stigmas 5, patent, obovate, $1 \mathrm{~mm}$ long, $0.6 \mathrm{~mm}$ wide, apex pleated, reflexed, upper surface glabrous, but with long papillae $0.6-0.8 \mathrm{~mm}$ long. Female flowers with tepals longer and broader than in the males. Fruits and seeds unknown. Fig. 1.

RECOGNITION. Differing from Cola clavata Mast. in that leaf-blades discolorous, light green above; white-green below (not \pm concolorous, dark grey-brown); outer perianth indumentum covering $50-60 \%$ surface, with two distinct hair classes, largest stellate hairs with arms directed along longitudinal axis of tepal (not 100\% coverage, a single hair type, stellate hair arms radiating), tepal number 5 (not $(5-) 6$ ); staminode number 5 (not (5-) 6). See Table 1 for additional characters. Distribution. Mozambique: Sofala Province, Cheringoma Plateau (Map 1).

SPECIMENS EXAMINED. MOZAMBIQUE. Sofala Province, Cheringoma. Condué Distr., near the sawmills of $\mathrm{Mr}$ M. Sol, fl. 6 Nov. 1957, Gomes e Sousa 4441 (holotype $\mathrm{K}$ !; isotypes K!, LMA!); ibid. st. 3 Dec. 1960, Gomes $e$ Sousa 4441A (K!); ibid. gallery forest of Condué R. $18^{\circ} 25^{\prime} \mathrm{S}, 35^{\circ} 02^{\prime} \mathrm{E}$ st. 11 Oct. 1961, Gomes e Sousa 4712 (K!); ibid. $18^{\circ} 40^{\prime} \mathrm{S}, 34^{\circ} 50^{\prime} \mathrm{E}$, st. 13 June 1962 , Gomes $e$ Sousa 4773 (K!); ibid. $18^{\circ} 45^{\prime} \mathrm{S}, 34^{\circ} 40^{\prime} \mathrm{E}$, st. 25 Aug. 1962, Gomes e Sousa 4786 (K!); ibid. st. 25 July 1962, Gomes e Sousa 4787 (K!); ibid. st. 12 Oct. 1962, Gomes e Sousa 4793 (K!); "near n. 4793, not opened flowers" 12 Oct. 1962, Gomes e Sousa 4793A (K!); ibid. Gomes e Sousa 4793B (K!); ibid. Gomes e Sousa 4793C (K!).

CONSERVATION STATUS. The ten specimens of Cola cheringoma derive from four points (Map 1), all of which are indicated by the collector as being gallery forest on limestone substrate. These points appear to correspond to the limestone gorge area of the Cheringoma Plateau, apparently the only limestone forest area currently confirmed in Mozambique (but see note below). The Cheringoma Formation of limestone forms a continuous belt along the northeastern boundary of the ZânguèUrema depression and covers wide areas north of the Búzi River (GTK Consortium 2006). The total area of the limestone is not known. The Cheringoma Plateau is aligned SSW to NNE, forming the eastern side of the southern end of the African Rift valley. Most of the northern half of the plateau is calcareous sandstone that hosts woodland. Underneath the sandstone is Eocene limestone, exposed by river cutting and at cliffs, the forest on it being restricted to the sides and floors of the gorges.

Across Mozambique, most of the surviving patches of lowland forest are threatened by clearance for agriculture, uncontrolled logging, and uncontrolled wildfires, so those that survive now exist as isolated patches (I. Darbyshire pers. comm. 2018). Around Inhaminga and Inhamitanga, whence two of the points occur, including the type specimen, the forest is being cleared for farmland and timber, so it is possible that the location for Cola cheringoma at this location has been lost completely (observations made on Google Earth, accessed 15 Sept. 2018). At Catapú near to Imhamitanga, a major international limestone mining extraction programme is intended to supply material for cement, aggregate and agrilimestone markets, facilitated by the proximity of the Beira-Tete railway (Premier African Minerals 2016). There is also evidence of limestone exploitation near Condué, where the natural vegetation is being cleared for 'borrow pits' and associated infrastructure. This includes the construction of access roads, which further fragment the surviving forest patches (Google Earth imagery 2018). This location is at the edge of the Gorongosa National Park, which offers some levels of protection. It is also probably protected within Coutada 12, a former hunting concession which is now under the control of Gorongosa, and which will likely eventually be included within the park (B. Wursten pers. comm. 2018).

The four points for Cola cheringoma equate to three threat-based locations as defined by IUCN. Using the georeferenced specimens cited in this paper, the area of occupancy (AOO) and extent of occurrence (EOO) have been calculated using GeoCat (Bachman et al. 2011). Both AOO and EOO are below the threshold for Endangered according to the IUCN categories and criteria $\left(\mathrm{AOO}=16 \mathrm{~km}^{2}, \mathrm{EOO}=292 \mathrm{~km}^{2}\right)$. Therefore, given the threats and the decline in both quality and extent of the habitat across this species range, Cola cheringoma is here assessed as Endangered Blab(iii)+B2ab(iii).

ETYMOLOGY. Named for the Cheringoma Plateau, to which this species seems restricted.

LOCAL NAMES. Sangala (in the local language according to Gomes e Sousa $4712(\mathrm{~K})$ ).

ECOLOGY. All ten specimens known for Cola cheringoma indicate that it grows in gallery forest of the river Condué on alluvial lime soil ("alluvionar lime-argillous soil”). The range of altitudes given is $180-200 \mathrm{~m}$ alt. The forest is characterised as 'dense subhygrophile' (Gomes e Sousa 4793 B). Although the river Condué has not yet been located by us with certainty, the reference to Cheringoma (Gomes e Sousa 4712) and the three grid references given (see specimens examined) allow us to conclude that this species occurs in the poorly explored limestone gorge area of the Cheringoma Plateau.

The Cheringoma limestone gorge forest appears to have been reported for the first time as a distinct vegetation type in Stalmans \& Beilfuss (2008). Those authors map the vegetation as "Limestone Gorge" 


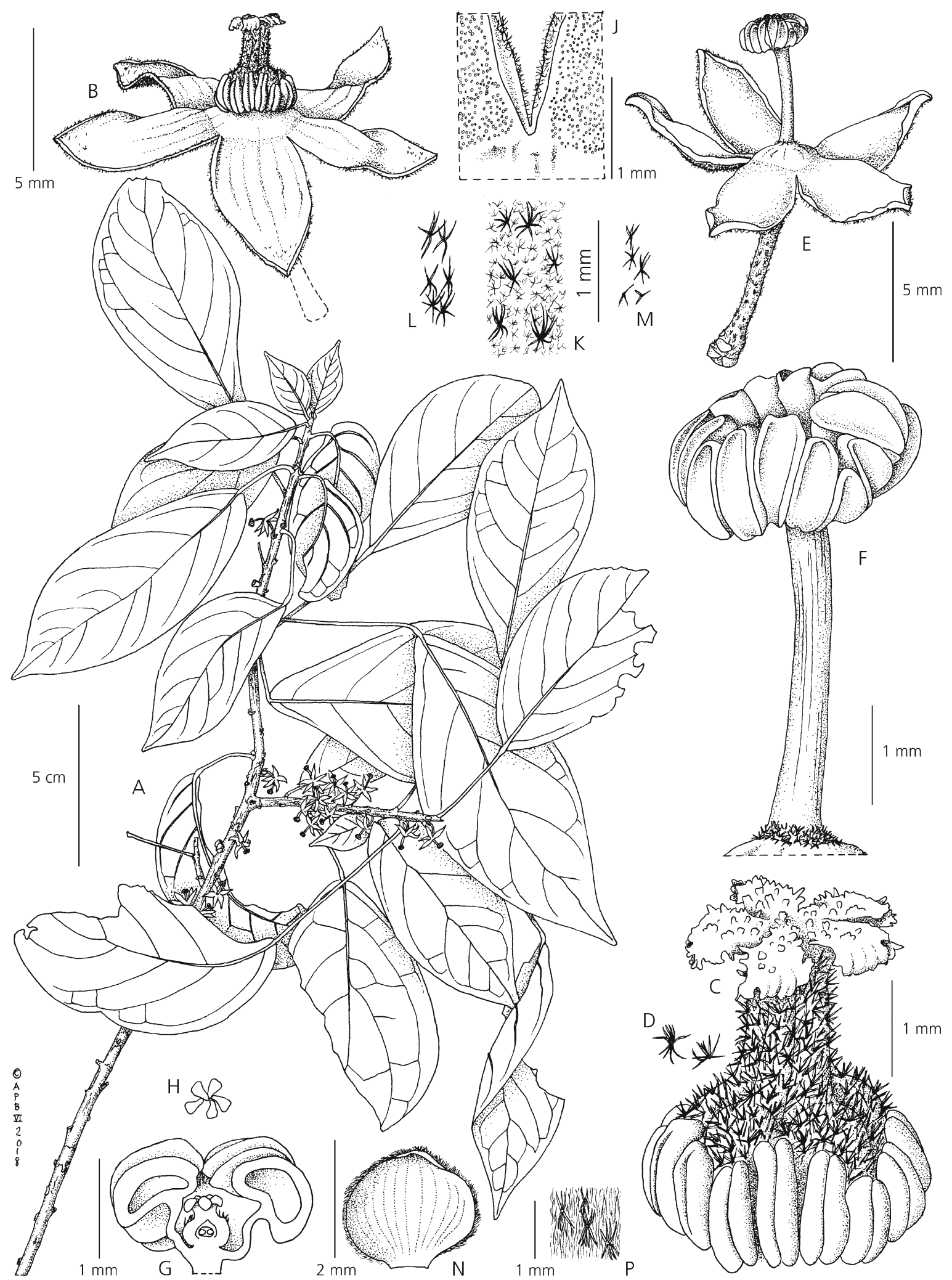

Fig. 1. Cola cheringoma. A habit, male flowering branch; B female flower; $C$ female flower from $B$, without perianth; $D$ detail of hairs from $C$; $E$ male flower; $F$ androecium from $E$; $G$ longitudinal section of anther head from $F$, showing the vestigial gynoecium within; $\mathrm{H}$ plan view of the style-stigmas from $\mathrm{G}$; J detail of the inner surface of the female perianth at the sinus between lobes; $\mathrm{K}$ indumentum from outer surface of perianth, female flower; $L$ indumentum from pedicel, female flower; $M$ indumentum from pedicel, male flower; $\mathbf{N}$ inner surface of outermost bract; $\mathbf{P}$ detail of indumentum of the outer surface of bract, from $\mathrm{N}$. All from Gomes e SOUsa 4441 (K). DRAWN BY ANDREW BROWN. 

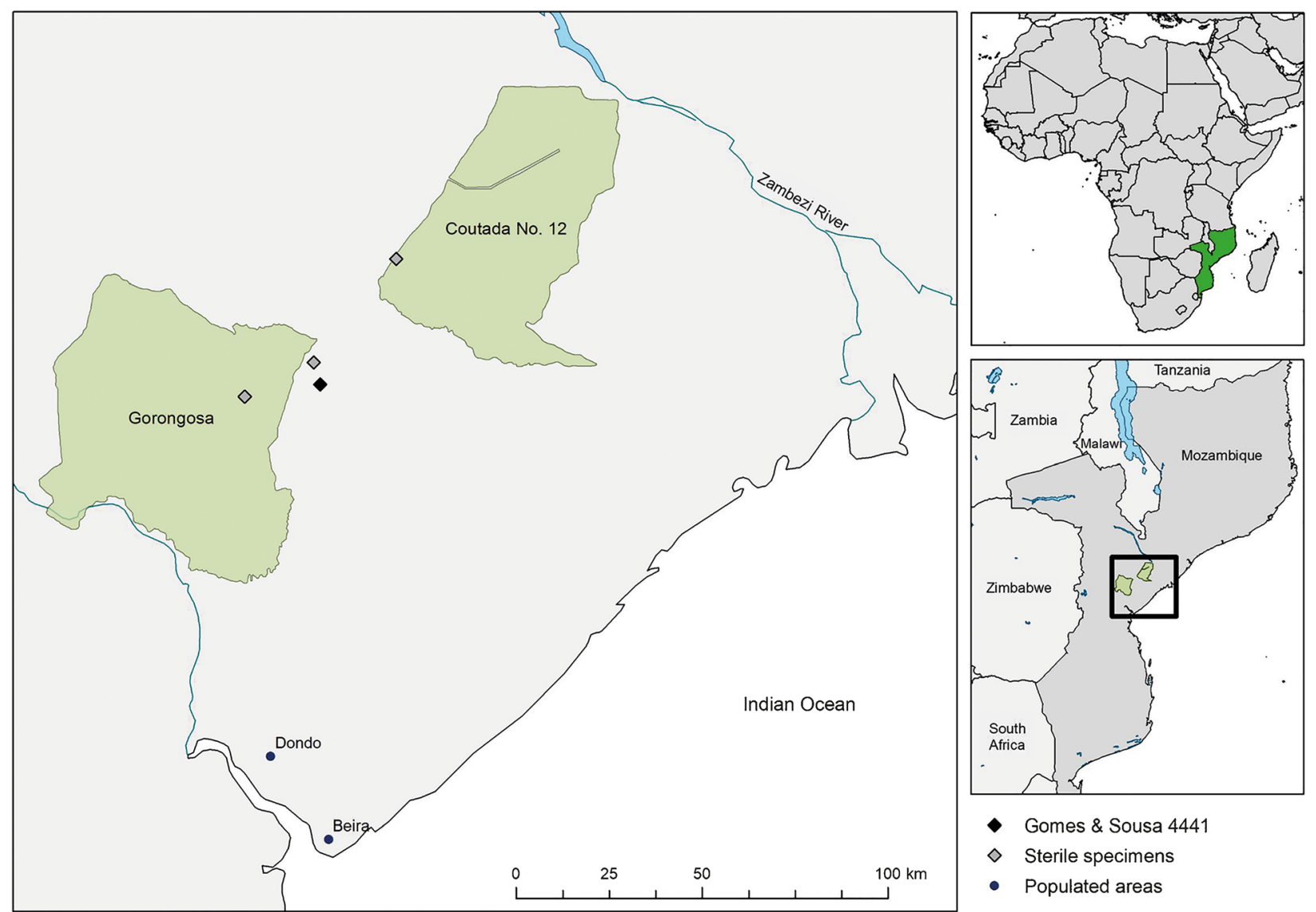

Map 1. Cola cheringoma sp. nov. of Mozambique, global distribution, showing protected areas. DESIGNED BY POPPY LAWRENCE.

within the Gorongosa National Park (GNP), depicting it as a slender irregular band about $0.5-1 \mathrm{~km}$ wide, consisting of c. $15000 \mathrm{Ha}$ extending along the length of the plateau where it is surrounded by calcareous sandstone. From this map and our data points we are aware that it extends outside the GNP and in total is perhaps $60 \mathrm{~km}$ long SSW to NNE. A succinct description of this vegetation is that of Burrows $e t a l$. (2018: 9 - 10): "A tall sheltered forest protected within the deep limestone gorges on the western edge of the Cheringoma Plateau, Sofala Province. Climate is very humid and hot (annual mean temperature $34^{\circ} \mathrm{C}$ ) with a mean annual rainfall of just over $1100 \mathrm{~mm}$, occurring at altitudes of 100 to $280 \mathrm{~m}$. The surrounding limestone shelf is dominated by Androstachys johnsonii. The sheltered and protected gorges harbour several very interesting and special species." The limestone was deposited in the Eocene (Anon., downloaded 17 Sept. 2018) and is nummulitic (Mercader \& Sillé 2013), including caves with stoneage remains. This vegetation type is not mapped in the Vegetation map of the Flora Zambesiaca area (Wild \& Barbosa 1967), probably because the scale used there is too coarse. In fact, the only limestone-based vegetation type included in that work is a savanna (woodland) type that occurs in central Zimbabwe.
Additional locations in Mozambique with limestone are documented in GTK Consortium (2006): "Limestones of the Tertiary Salamanga Formation, south of Maputo, of the Cheringoma Formation west of Beira along the Buzi River and in the type locality north of Beira on the Cheringoma Plateau, have high calcium carbonate contents. The Miocene Jofane Formation is a second important accumulation of limestone. A large area with limestone outcrops extends from the Save River southwards to Inhambane. Limestone occurrences are also known at Urrongas". Thus, there may be as many as five other limestone locations in Mozambique, although some of these may be subsurface and so may not support calcicole plants, and if that is not the case may not support forest. Several of these sites are already active limestone quarries and any narrow endemics present may have become extinct.

No detailed documentation of the limestone gorge vegetation was available until recently when an unpublished checklist of about c. 320 species by Burrows et al. (2012) was made. Coates-Palgrave et al. (2007) published a survey of the woody flora and vegetation at Catapú, near Inhamitanga, which is in the vicinity of the limestone, but that study does not refer to any vegetation on limestone, even 
though a prospective limestone mine occurs at the northern boundary of Catapú (see conservation section).

PHENOLOGY. Flowering occurs in early November after the southern rains begin (Gomes e Sousa 4441) in September. New shoots are extended in October (Gomes e Sousa 4712). By early December only the presence of numerous old floral bracts shows that flowering has occurred, and the apical stem buds are already dormant (Gomes e Sousa 4441A). Through June, July, August to October, new axillary floral buds develop while the stem apex remains dormant (Gomes e Sousa 4773, 4786, 4787, 4793, 4793A, 4793B). It is clear that the flowering period is brief, since, of ten specimens made throughout the year, only one is in flower.

DIOECY. There is not enough evidence available to determine whether Cola cheringoma is dioecious or monoecious. The single flowering sheet had all male flowers on the branch, and a pocket with further male flowers, and a single female flower. It is not possible to be certain whether the female was from the same tree as the male, although this seems most likely, in which case the species is monoecious. POPULATION. On his specimen labels, Gomes e Sousa often gives an indication of the number of individuals that he observed. This varies from a single individual (Gomes e Sousa 4441), to two individuals (Gomes e Sousa 4712), to three (Gomes $e$ Sousa 4773), to 'frequent in that place' (Gomes $e$ Sousa 4786, 4787) to 'common' (Gomes e Sousa 4793 A-C).

\section{Discussion}

\section{New species}

Approximately 2000 new flowering plant species are described each year (Willis 2017), adding to the estimated 369,000 already known to science (Nic Lughadha et al. 2016) although this total is disputed (Nic Lughadha et al. 2017). Widespread species tend to have already been discovered, so that many newly discovered species are those that are range-restricted and so are much more likely to be threatened, such as Cola cheringoma. Evidence-based conservation assessments exist for about $21-26 \%$ of known species, and $30-44 \%$ of these assessments rate the species concerned as threatened (Bachman et al. 2018). This makes it imperative to discover and publish such species so that they can assessed, and, if merited, conservation actions taken to reduce their extinction risks, such as through designating and implementing Important Plant Areas (Darbyshire et al. 2017).

Cola cheringoma is one of numerous rangerestricted species new to science discovered in Mozambique in recent years, mainly in connection with the Trees \& Shrubs of Mozambique project (Burrows et al. 2018) and the Tropical Important Plant Areas Project (Darbyshire et al. 2017). Due to the unrest associated with the war of independence (1964 - 1975) and subsequent civil war (1977 1992), Mozambique had experienced a long period of relative neglect in terms of biodiversity research. In the last 15 years this has changed to an upsurge in botanical exploration and discovery as reported in Cheek et al. (2018c). Since that date Olinia chimanimani T.Shah (Shah et al. 2018) from Chimanimani and Eriolaena rulkensii Dorr in the Dombeyaceae (Dorr \& Wurdack 2018) from near Pemba in NE Mozambique have been published. The latter is the first time that a member of this genus, previously thought restricted to Asia, has been recognised in continental Africa. Similarly, Erythrina madagascariensis Du Puy \& Labat, previously thought restricted to Madagascar and the Comoro Islands, has also been recently discovered in NE Mozambique (see Burrows et al. 2018). More exciting species discoveries in Mozambique are expected as botanical exploration continues. The species richness is likely to be the highest of the Flora Zambesiaca region although due to under-exploration, the total species number is unknown. New surveys at botanically interesting sites in Mozambique are constantly producing new country records and new species.

\section{African Limestone forest with Cola species}

Although Cola species are almost ubiquitous in good quality forest in tropical Africa, limestone (calcium carbonate) surface outcrops are very rare in those areas with sufficient precipitation to support forest, as opposed to woodland or thicket. Surprisingly, there seems to be no overview of limestone forest areas in Africa, but much useful data for Kenyan and Tanzanian forest on limestone is contained in Hawthorne (1984). Hawthorne (1984) mapped three types of limestone. The most recently formed is that on the coast: Neogene or quaternary coral rag, formed from recently uplifted coral platforms and breccia. Further inland is Jurassic oolitic limestone, weathered into pinnacles and ridges (often known as karst). This occurs mainly in southern Kenya (Kambe limestone) and outcrops also near Tanga in northern Tanzania (Tanga limestone). Finally, still further inland, and further to the south, forming foothills to the crystalline Uluguru Mts, are the palaeozoic marble limestones of the Kimboza and Mandambala Hills in Tanzania (Hawthorne 1984).

Table 2 documents all the known forested limestone outcrop locations in tropical Africa on which Cola species occur. These are confined to only three countries: Kenya, Tanzania and Mozambique. Of the currently known 13 locations, 10 occur in Kenya 


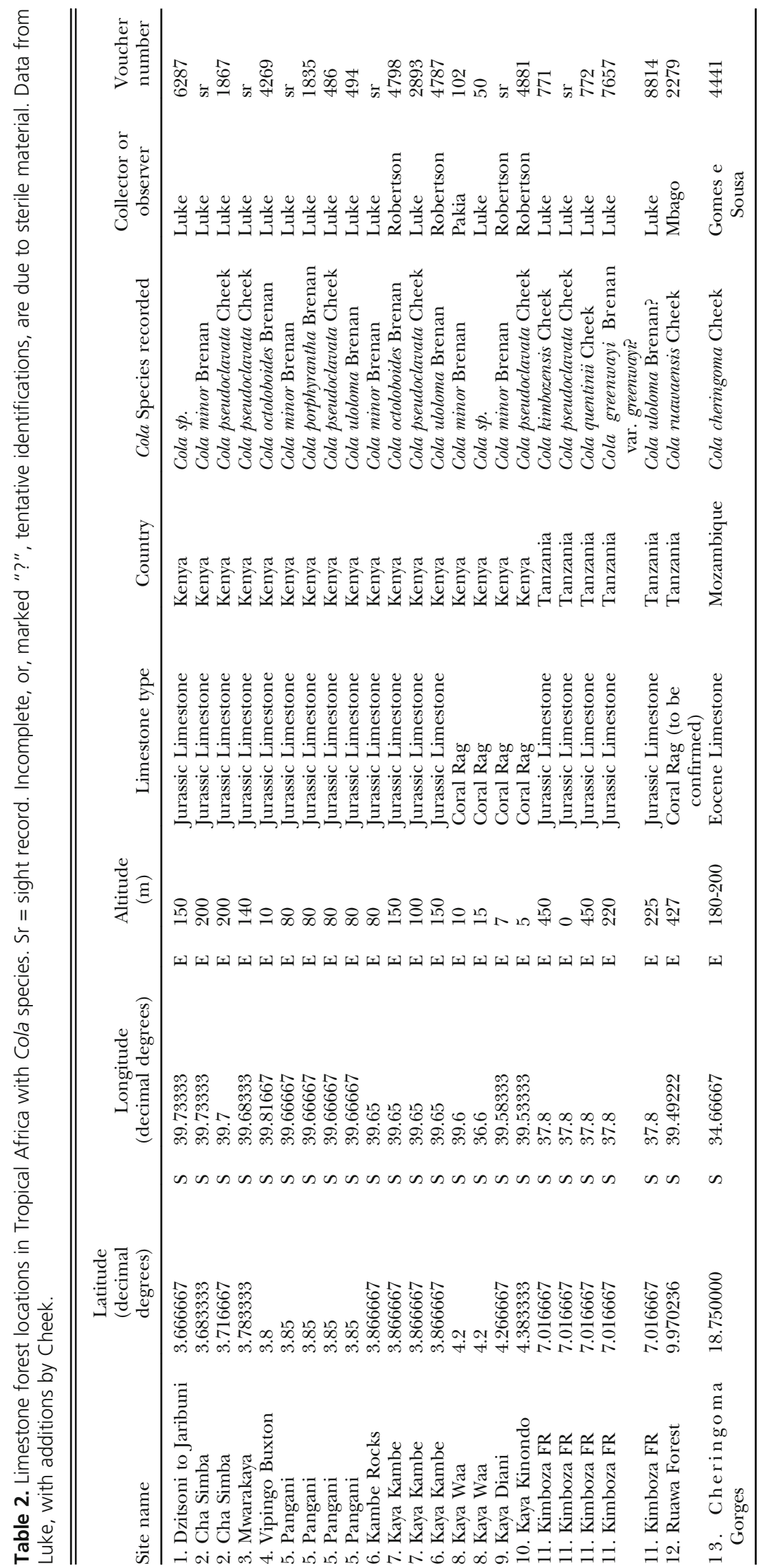


(Map 2). Forest on limestone outcrops appears to be unknown in West and Congolian Africa. While continental Africa may have as much as $20 \%$ of its surface with carbonate present according to remote sensing studies (Williams \& Fong 2016), most of this occurs outside the tropical forest belt, particularly in North and Saharan Africa, and in the arid NE. Those carbonate areas which have been mapped in forest areas e.g. in southern Nigeria, Cameroon or DRC (Williams \& Fong 2016), appear to be either so low in concentration of carbonate, or so deeply buried under soil, that they are not detectable to botanists and have no impact on the vegetation above them (Cheek, Luke, pers. obs. 1984 - 2018).

Additional forests on limestone, from which Cola have not been reported, are few. The Kingupira forest in the eastern Selous occurs on Jurassic limestone and extends for c. $5 \mathrm{~km}^{2}$. However, this is a Groundwater Forest, where moving water occurs close to the surface. In addition, a thin layer of soil intervenes over the limestone (Vollesen 1980: $10-11)$. Therefore, this site may not equate to other forests on limestone which are free-draining, and lack such soil coverage. At least parts of Matumbi-Kichi-Tendaguru, near Kilwa in coastal Tanzania had dry coastal forest in the 1980's and 90's (Vollesen pers. comm. to Cheek, Sept. 2018), but these are not known to either survive, or to have been well surveyed.

Numerous plant species have evolved to adapt to the physiological challenges of growing on a limestone substrate. Some can only grow on limestone (obligate calcicole species) while others can grow both on and off the substrate (facultative calcicoles). Obligate calcicoles are often restricted to single or very few limestone patches and so are narrowly endemic, such as, in Gesneriaceae, Streptocarpus kimbozensis B.L.Burtt.and Saintpaulia ionantha Wendl. subsp. rupicola (B.L.Burtt) I.Darbysh. (Darbyshire 2006), or in Meliaceae, Turraea kimbozensis Cheek (Cheek 1989) and in Acanthaceae Isoglossa asystasioides I.Darbysh. \& Ensermu (Darbyshire \& Ensermu Kelbessa 2007) and Justicia lukei Vollesen (Darbyshire et al. 2010). The highly restricted distribution of these species and the
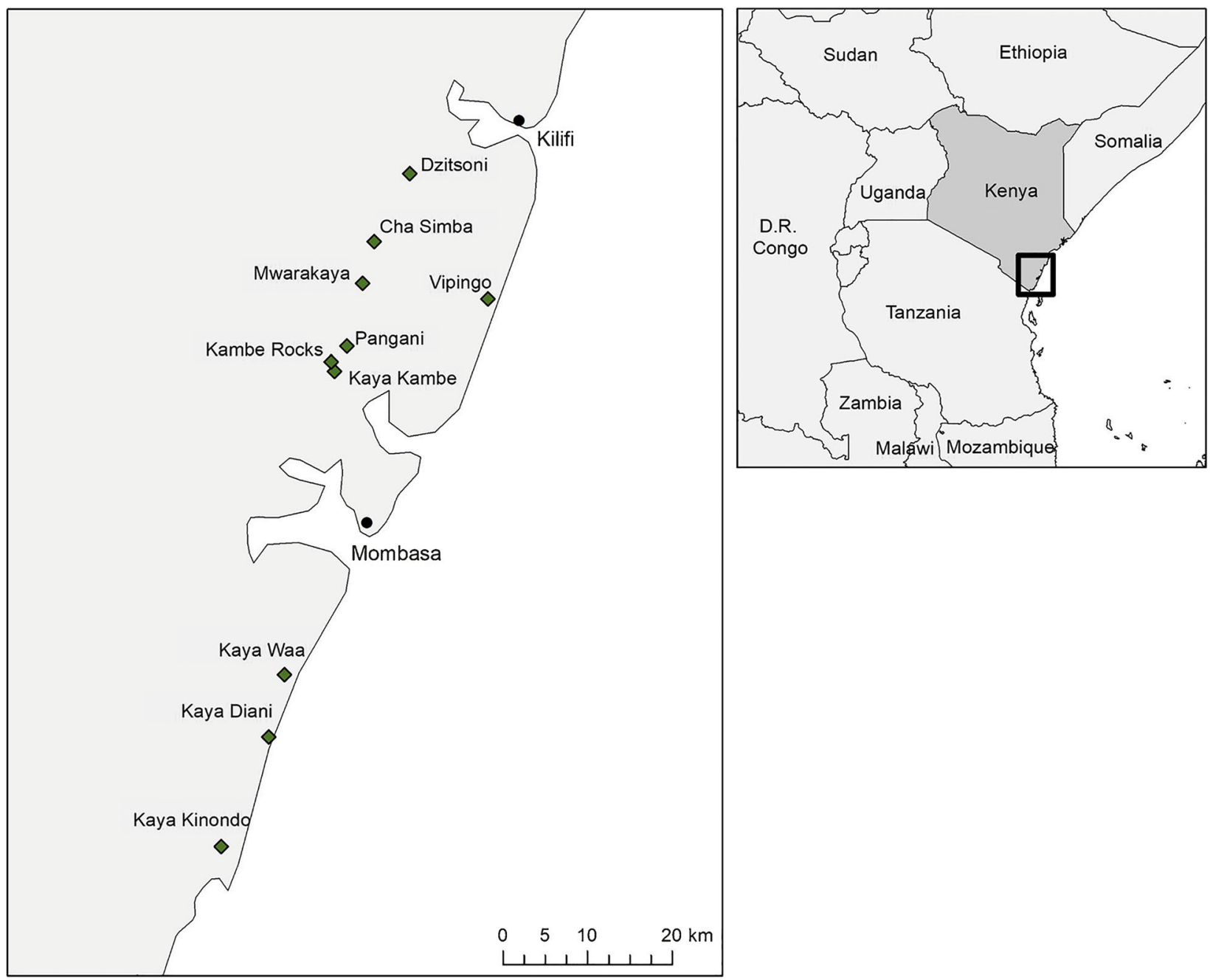

Map 2. Distribution of the ten limestone forest locations with Cola in Kenya. DESIGNED BY POPPY LAWRENCE. 


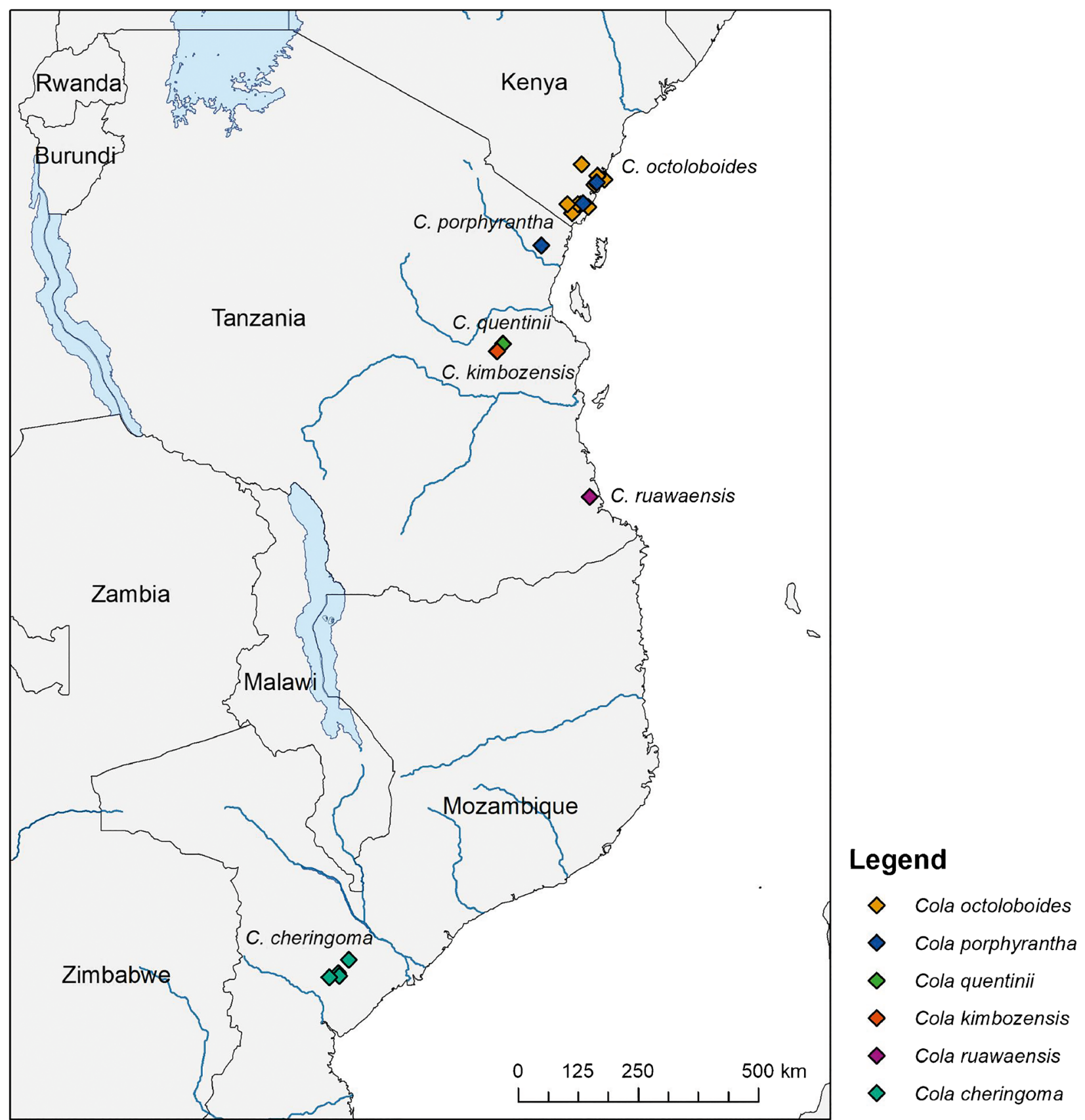

Map 3. Distribution of all obligate and of key facultative forest calcicole Cola species in Africa. DESIGNED BY POPPY LAWRENCE.

threats that their habitat faces from tree-cutting for timber or charcoal, quarrying of the limestone substrate for cement, building stone or marble, makes them especially threatened. It is the geologically oldest limestone area that has the greatest number of point endemics: the 385 ha of the Kimboza forest have eleven strictly endemic species (Cheek \& Dorr 2007, citing data mainly from Luke).

Cola cheringoma is only known from the Cheringoma limestone area and is likely to be specific to the substrate at this location. To the north, in Tanzania, just over the border near Lindi, C. ruwaensis Cheek is also restricted, to an area of coastal limestone, while further north still, C. kimbozensis Cheek, and C. quentinii Cheek are also both obligate calcicoles, restricted to the palaeozoic marble limestone of the Kimboza Forest in Tanzania which is probably the richest site for forest limestone point endemic plant species in tropical Africa (Cheek \& Dorr 2007: 31 - 32).

Cola uloloma Brenan, C. porphyrantha, Brenan, C. octoloboides Brenan, C. pseudoclavata Cheek, and C. minor Brenan of coastal Kenya and Tanzania are all facultative calcicoles, occurring in forest both on limestone, usually but not always coral rag, and off limestone, e.g. on volcanic 
substrate (e.g. Cola octoloboides at Zombo in Kenya - Luke pers. obs.). Fourteen other species of Cola in East Africa (Uganda, Kenya and Tanzania) are not known to occur on limestone (Cheek \& Dorr 2007). The limestone Cola species appear from their morphology to comprise four different clades. Each putative clade, still to be supported by molecular phylogenetic analysis, has one or more facultative calcicole species and a single obligate calcicole species.

While Cola quentinii and C. porphyrantha are part of the 'Cola stelechantha' group, C. ruwaensis and Cola octoloboides form a distinctive and entirely morphologically separate, species-pair (Cheek \& Dorr 2007). Cola kimbozensis has no obvious connection to the foregoing groups. Cola cheringoma appears to be a fourth radiation onto limestone from a probable nonlimestone specific ancestor, possibly shared with the geographically and morphologically close C. clavata which is not known from limestone substrates, although the equally closely similar C. pseudoclavata Cheek, and C. minor Brenan, are both facultative calcicoles, from further north, in southern Kenya and northern Tanzania (see Table 2 and Map 3).

At the moment, Cola cheringoma is the only endemic plant species known from the Cheringoma limestone. This is likely to be an artefact of under-collection. With further targeted surveys to this habitat, additional new calcicole species are likely to be discovered.

\section{Acknowledgements}

The impetus to resuscitate the revision of Cola was provided by sponsorship via IUCN from the Toyota Motor Corporation to the R.B.G., Kew Plant Assessment Unit (PAU) to increase assessment output of plant species. This resulted in support by Eimear Nic Lughadha and Serene Hargreaves for an internship specifically to assess the conservation status of Cola species (Poppy Lawrence), necessitating renewed work on species delimitation of that genus by the first author to support these. Hermenegildo Matimele and Aurélio Banze thank Camilla Sousa at LMA for her support, and the Bentham Moxon Trust for funding their visit to Kew in which they collected data contributing to this paper. Thanks to Clayton Langa at LMA for finding the type specimen and relating to us its annotations. Marc Stalmans at Gorongosa National Park, David Goyder and Bart Wursten are thanked for information on the Cheringoma area. Barbara Turpin at BNRH kindly provided scans of all specimens of Cola at her herbarium. Peris Kamau at EA also kindly checked for duplicates of the type. Alexandre Monro is thanked for discussions on global limestone literature, Pablo Hendrigo for information on newly discovered Brazilian calcicoles, Iain Darbyshire and Kaj Vollesen for data and discussions on limestone and plants in Tanzania. Anne Marshall expertly detected and retrieved relevant literature. Janis
Shillito is thanked for typing the manuscript, Isabel Baldwin for software expertise, Marc Stalmans and Laurence J. Dorr and an anonymous reviewer for valuable comments on an earlier version of this paper.

Open Access This article is distributed under the terms of the Creative Commons Attribution 4.0 International License (http://creativecommons.org/ licenses/by/4.0/), which permits unrestricted use, distribution, and reproduction in any medium, provided you give appropriate credit to the original author(s) and the source, provide a link to the Creative Commons license, and indicate if changes

were made.

\section{References}

Anon. (2018). Cheringoma Plateau. Accessed 15 Sept. 2018: https://en.wikipedia.org/wiki/ Cheringoma_Plateau

Araújo, A. O., Souza, V. C. \& Perret, M. (2010). Chautemsia calcicola: A new genus and species of Gloxinieae (Gesneriaceae) from Minas Gerais, Brazil. Taxon 59: 203 - 208. https://doi.org/ 10.1002/tax.591019.

Bachman, S., Moat, J., Hill, A., de la Torre, J. \& Scott, B. (2011). Supporting Red List threat assessments with GeoCAT: geospatial conservation assessment tool. ZooKeys 150: 117 - 126. https://doi.org/ 10.3897/zookeys.150.2109.

, Nic Lughadha, E. M. \& Rivers, M. C. (2018). Quantifying progress towards a conservation assessment for all plants. Conserv. Biol. https://doi.org/ 10.1111/cobi.13071.

Baum, D. A., Alverson, W. S. \& Nyffeler, R. A. (1998). A durian by any other name: taxonomy and nomenclature of the core Malvales. Harvard Pap. Bot. 3: 315 - 330 .

Bayer, C., Fay, M. F., De Bruijn, A. Y., Savolainen, V., Morton, C. M., Kubitzki, K., Alverson, W. S. \& Chase, M. W. (1999). Support for an expanded family concept of Malvaceae within a recircumscribed order Malvales: a combined analysis of plastid atpB and rbcL DNA sequences. Bot. J. Linn. Soc. 129: 267 - 303. https://doi.org/10.1111/ j.1095-8339.1999.tb00505.x.

\& Kubitzki, K. (2003). Malvaceae. In: K. Kubitzki \& C. Bayer (eds), The families and genera of vascular plants 5: flowering plants dicotyledons, pp. 225 - 311. Springer-Verlag, Berlin.

Brenan, J. P. M. \& Keay, R. W. J. (1955). Hooker's Icon. Pl. t. $3529-3537$.

Burrows, J., Burrows, S., Lötter, M. \& Schmidt, E. (2018). Trees $\mathcal{E}$ Shrubs Mozambique. Print Matters Heritage. Cape Town. 
McCleland, W. \& Schmidt, E. (2012). Check-list of the plants recorded at the limestone gorges, Cheringoma Plateau. Unpublished report. Gorongosa National Park.

Castro, R. M. \& Rapini, A. (2006). Four new species of Moraceae from Bahia, Brazil. Neodiversity 1: $13-20$. https://doi.org/10.13102/neod.12.2.

Carvalho-Sobrinho, J. G. \& Queiroz, L. P. (2008). Ceiba rubriflora (Malvaceae: Bombacoideae), a new species from Bahia, Brazil. Kew Bull. 63: 649 - 653. https://doi.org/10.1007/s12225-008-9070-6.

Cheek, M. (1989). A new species of Turraea (Meliaceae) from Tanzania. Kew Bull. 44(3): 465 468. https://doi.org/10.2307/4110366.

(2002a). Three new species of Cola (Sterculiaceae) from western Cameroon, Cameroon. Kew Bull. 57: 402 - 415. https://doi.org/10.2307/4111117.

(2002b). A new species of Cola (Sterculiaceae) from the Usambara Mts, Tanzania. Kew Bull. 57: 417 - 422. https://doi.org/10.2307/4111119.

, Chipanga, H. \& Darbyshire, I. (2018c). Notes on the plant endemics of the quartzitic slopes of $\mathrm{Mt}$ Chimanimani (Mozambique \& Zimbabwe), and a new, Critically Endangered species, Empogona jenniferae (Rubiaceae-Coffeeae). Blumea 63(1): 87 92. https://doi.org/10.3767/blumea.2018.63.01.08.

\& Dorr, L. (2007). Sterculiaceae. Flora of Tropical East Africa. Royal Botanic Gardens, Kew.

Jebb, M., Murphy, B. \& Mambor, F. (2018b). Nepenthes section Insignes in Indonesia, with two new species. Blumea 62(3): 174 - 178. https://doi.org/ 10.3767/blumea.2018.62.03.03.

, Lawrence, P. \& McCleland, W. (2018a). Cola dorrii sp. nov. (Sterculiaceae), a threatened Maputaland Forest endemic of South Africa. Kew Bull. 73(25). https://doi.org/10.1007/s12225-018-9749-2.

Mackinder, B., Gosline, G., Onana, J.-M. \& Achoundong, G. (2001). The phytogeography and flora of western Cameroon and the Cross RiverSanaga River interval. Syst. Geogr. Pl. 71: 1097 1100. https://doi.org/10.2307/3668742.

Chung, K. F., Leong, W. C., Rubite, R. R., Repin, R., Kiew, R., Liu, Y. \& Peng, C. I. (2014). Phylogenetic analyses of Begonia sect. Coelocentrum and allied limestone species of China shed light on the evolution of Sino-Vietnamese karst flora. Bot. Stud. (Taipei) 55(1): 1. https://doi.org/10.1186/1999-3110-55-1.

Coates-Palgrave, M., van Wyk, A. E., Jordaan, M., White, J. A. \& Sweet, P. (2007). A reconnaissance survey of the woody flora and vegetation of the Catapú logging concession, Cheringoma District, Mozambique. Bothalia 37(1): 57 - 73. https:// doi.org/10.4102/abc.v37i1.303.

Darbyshire, I. (2006). Gesneriaceae. Flora of Tropical East Africa. Royal Botanic Gardens, Kew.

Anderson, S., Asatryan, A., Byfield, A., Cheek, M., Clubbe, C., Ghrabi, Z., Harris, T., Heatubun, C. D., Kalema, J., Magassouba, S., McCarthy, B., Milliken,
W., de Montmollin, B., Nic Lughadha, E., Onana, J. M., Saidou, D., Sarbu, A., Shrestha, K. \& Radford, E. A. (2017). Important Plant Areas: revised selection criteria for a global approach to plant conservation. Biodivers. Conserv. 26: 1767 - 1800. https:// doi.org/10.1007/s10531-017-1336-6.

\& Ensermu Kelbessa (2007). Isoglossa asystasioides, a striking new species of Acanthaceae from Tanzania. Kew Bull. 62: 617 - 621.

Vollesen, K. \& Ensermu Kelbessa (2010). Acanthaceae (part II). In: H. Beentje (ed.), Flora of Tropical East Africa. Royal Botanic Gardens, Kew.

Dorr, L. J. \& Wurdack, K. J. (2018). A new disjunct species of Eriolaena (Malvaceae, Dombeyoideae) from continental Africa. Phytokeys 111: 1 - 16. https://doi.org/10.3897/phytokeys.111.29303.

Esri ArcWorld Database [computer file] (1992). Environmental Systems Research Institute, Redlands, CA

Fiaschi, P. (2014). Three new species and a revised key to species of Oxalis section Polymorphae (Oxalidaceae). Brittonia 66: 134 - 150. https:// doi.org/10.1007/s12228-013-9315-z.

Germain, R. (1963). Cola, pp. 277 - 316, in Sterculiaceae. In: Flore du Congo $\mathcal{E}^{\circ} d u$ Rwanda et du Burundi. Spermatophytes 10.

Gomes e Sousa, A. (1967). Dendrologia de Moçambique. Série Memórias, No. 1. (2 vols). Instituto de Investigação Agronómica de Moçambique, Lourenço Marques.

Google Earth Imagery (2018).

GTK Consortium (2006). Map Explanation; Vol. 2: Sheets 1630 - 1934. Geology of Degree Sheets Mecumbura, Chioco, Tete, Tambara, Guro, Chemba, Manica, Catandica, Gorongosa, Rotanda, Chimoio and Beira, Mozambique. Ministério dos Recursos Minerais, Direcção Nacional de Geologia, Maputo. http://tupa.gtk.fi/julkaisu/ specialpaper/sp_048_pages_307_321.pdf

Hallé, N. (1961). Cola (Sterculiaceae). In: A. Aubréville, Flore du Gabon 2: 38 - 104. Muséum national d'histoire naturelle, Paris.

Hawthorne, W. (1984). Ecological and biogeographical patterns in the coastal forests of East Africa. PhD thesis. University of Oxford. Unpubl.

Heywood, V. H., Brummitt, R. K., Culham, A. \& Seberg, O. (eds) (2007). Flowering plant families of the world. Royal Botanic Gardens, Kew.

IPNI (continuously updated). The International Plant Names Index. http://ipni.org/.

IUCN (2012). IUCN Red List Categories and Criteria: Version 3.1. Second edition. IUCN, Gland and Cambridge. Available from: http:// www.iucnredlist.org/ (accessed: 01/2017).

UNEP-WCMC (2017). The World Database on Protected Areas (WDPA) [On-line], November 2017 (version 3.1). Cambridge, UK: UNEP-WCMC. Available at: www.protectedplanet.net. 
Keay, R. W. J. \& Brenan, J. P. M. (1958). Cola. In: R. W. J. Keay (ed.), Flora of West Tropical Africa Vol. 1, part 2: 321 - 332. Crown Agents, London.

Kenfack, D., Sainge, M. N., Chuyong, G. B. \& Thomas, D. W. (2018). The genus Cola (Malvaceae) in Cameroon's Korup National Park, with two novelties. Pl. Ecol. Evol. 151(2): 241 - 251. https:// doi.org/10.5091/plecevo.2018.1410.

Mercader, J. \& Sillé, P. (2013). Middle and later stoneage sites from Sofala, Gorongosa (Central Mozambique). Nyame Akuma 80: 1 - 13.

Monro, A. K., Wei, Y. G. \& Chen, C. J. (2012). Three new species of Pilea (Urticaceae) from limestone karst in China. PhytoKeys 19: 51 - 66. https:// doi.org/10.3897/phytokeys.19.3968.

Nic Lughadha, E., Bachman, S. P. \& Govaerts, R. (2017). Plant Fates and States: Response to Pimm \& Raven. Trends Ecol. Evol. 32: 887 - 889. https:// doi.org/10.1016/j.tree.2017.09.005.

, Govaerts, R., Belyaeva, I., Black, N., Lindon, H., Allkin, R., Magill, R. E. \& Nicolson, N. (2016). Counting counts: Revised estimates of numbers of accepted species of flowering plants, seed plants, vascular plants and land plants with a review of other recent estimates. Phytotaxa 272: 82 - 88 . https://doi.org/10.11646/phytotaxa.272.1.5.

Onana, J-M. \& Cheek, M. (2011). The Red Data Book, Plants of Cameroon. Royal Botanic Gardens, Kew.

Premier African Minerals (2016). Catapú Limestone Project. Accessed 18 Sept. 2018: https:// www.premierafricanminerals.com/mozambique/ catapu-limestone-project

Sang, J., Kiew, R. \& Geri, C. (2013). Revision of Begonia (Begoniaceae) from the Melinau Limestone in Gunung Mulu National Park and Gunung Buda National Park, Sarawak, Borneo, including thirteen new species. Phytotaxa 99: 1): 1 - 1):34. https:// doi.org/10.11646/phytotaxa.99.1.1.

Schumann, K. (1900). Sterculiaceae Africanae. In: A. Engler, Monographieen afrikanischer Pflanzen-Familien und-Gattungen V. W. Engelmann, Leipzig.

Shah, T., Darbyshire, I. \& Matimele, H. (2018). Olinia chimanimani (Penaeaceae), a new species endemic to the Chimanimani Mountains of Mozambique and Zimbabwe. Kew Bull. 73: 36. https://doi.org/ $10.1007 / \mathrm{s} 12225-018-9757-2$.

Simpson, D. A., Muasya, A. M., Chayamarit, K., Parnell, J. A., Suddee, S., Wilde, B. D., Jones, M. B., Bruhl, J. J. \& Pooma, R. (2005). Khaosokia caricoides, a new genus and species of Cyperaceae from Thailand. Bot. J. Linn. Soc. 149(3): 357 - 364. https://doi.org/ 10.1111/j.1095-8339.2005.00446.x.

Skema, C. (2012). Toward a new circumscription of Dombeya (Malvales: Dombeyaceae): A molecular phylogenetic and morphological study of Dombeya of Madagascar and a new segregate genus, Andringitra. Taxon 61(3): 612 - 628. https://doi.org/10.1002/tax.613010.
Stalmans, M. \& Beilfuss, R. (2008). Landscapes of the Gorongosa National Park. Gorongosa National Park. Mozambique.

Thiers, B. (continuously updated). Index Herbariorum: A global directory of public herbaria and associated staff. New York Botanical Garden's Virtual Herbarium. Available from: http://sweetgum.nybg.org/ ih/. Accessed Sept 2018.

Turland, N. J., Wiersema, J. H., Barrie, F. R., Greuter, W., Hawksworth, D. L., Herendeen, P. S., Knapp, S., Kusber, W.-H., Li, D.-Z., Marhold, K., May, T. W., McNeill, J., Monro, A. M., Prado, J., Price, M. J. \& Smith, G. F. (ed.) (2018). International Code of Nomenclature for algae, fungi, and plants (Shenzhen Code) adopted by the Nineteenth International Botanical Congress Shenzhen, China, July 2017. Regnum Veg. 159. Koeltz Botanical Books, Glashütten.

Turner, I. M., Tan, J. P. C. \& Utteridge, T. M. A. (2018). From stowaways to karst-aways: unloading the Peninsular Malaysia endemic Polyalthia brunneifolia (Annonaceae): https://doi.org/10.1111/njb.01693

Vollesen, K. (1980). Annotated checklist of the Vascular Plants of the Selous Game Reserve, Tanzania. Opera Botanica 59.

Wild, H. (1961). Sterculiaceae. In: A. W. Exell (ed.), Flora Zambesiaca 1 (2): 517 - 564. Published on behalf of the Governments of Portugal, the Federation of Rhodesia and Nyasaland, and the United Kingdom by the Crown Agents for Oversea Governments and Administration, London. \& Barbosa, L. A. G. (1967). Vegetation Map of the Flora Zambesiaca Area. Flora Zambesiaca supplement. M. O. Collins, Salisbury.

Wilkie, P., Clark, A., Pennington, R. T., Cheek, M., Bayer, C. \& Wilcock, C. C. (2006). Phylogenetic Relationships within the subfamily Sterculioideae (Malvaceae/Sterculiaceae-Sterculieae) using the chloroplast gene ndhF. Syst. Bot. 31: 160 - 170. https://doi.org/10.1600/036364406775971714.

Wilkins, C. F. \& Whitlock, B. A. (2012). A revision of Commersonia including Rulingia (Malvaceae s.l. or Byttneriaceae). Austral. Syst. Bot. 25(1): 226 283. https://doi.org/10.1071/SB10031_CO.

Williams, P. \& Fong, Y. T. (2016). World map of carbonate rock outcrops v3.0. http://web.env.auckland.ac.nz/ our_research/karst. Accessed 19 Sept. 2018.

Willis, K. (2017). The state of the world's plants report2017. Royal Botanic Gardens, Kew.

Wursten, B. (2014). Cheringoma Biodiversity Survey 2013 - Botany report. Gorongosa National Park. Unpubl.

\section{Publisher's Note}

Springer Nature remains neutral with regard to jurisdictional claims in published maps and institutional affiliations. 